\title{
Short communication: The dissimilarity in plant species composition of savanna ecosystem along the elevation gradient on Flores Island, East Nusa Tenggara, Indonesia
}

\author{
SUTOMO^, I DEWA PUTU DARMA, RAJIF IRYADI \\ Research Centre for Plant Conservation and Botanic Garden-Indonesian Institute of Sciences (LIPI): Research station Bali Botanical Garden, \\ Candikuning, Baturiti, Tabanan, Bali 82191, Indonesia, `email: tommo.murdoch@gmail.com, masrajifgeo@gmail.com
}

Manuscript received: 2 September 2019. Revision accepted: 11 January 2020.

\begin{abstract}
Sutomo, Darma IDP, Iryadi R. 2020. Short communication: The dissimilarity in plant species composition of savanna ecosystem along the elevation gradient on Flores Island, East Nusa Tenggara, Indonesia. Biodiversitas 21: 492-496. Savannas in Indonesia are located from west to the east across the archipelago. The objective of this research was to investigate the dissimilarity of floristic composition among savannas at different elevations in Flores. Sixteen sampling plots, each measuring 20 x $20 \mathrm{~m}$ were spread over the lowland, midland, and upland savannas. We analyzed the differences in plant community composition among the savannas using NMDS ordination and SIMPER analyses available in PRIMER V.6. As many as 41 species of plants were found in all of the sampling plots. The lowland savanna plant community consisted of Themeda arguens, Zoesya sp., Chromolaena odorata, Crotalaria sp., Adenanthera pavonina, Ocimum sp., Lantana camara in the groundcover layer, and Ziziphus jujube, and Borassus flabellifer at the tree layer. The midland savanna had almost similar composition, except the occurrence of Imperata cylindrica and Leucaena leucocephala, and the upland savanna plant species were Cyperus sp., Polygala paniculata, I. cylindrica, Melastoma malabathricum, C. odorata, Centella asiatica, Vaccinium sp., and Cymbopogon sp. The savannas in Flores were invaded by invasive exotic species, namely L. camara and $C$. Odorata which may pose serious threat to the existence of savannas.
\end{abstract}

Keywords: Chromolaena odorata, elevation, Flores, Imperata cylindrica, savanna

Abbreviations: NMDS: Non-metric Multidimensional Scaling; ANOSIM: analysis of similarity; SIMPER: Similarity Percentage; GPS: Global Positioning System

\section{INTRODUCTION}

Savannas are ecosystems typically characterized by a continuous cover of $\mathrm{C}_{4}$ grasses and where woody plants are also an important feature, but with meager cover and no closed canopy (Frost et al. 1986). The most widespread and well-studied savanna ecosystems include Eucalyptus woodlands in northern Australia (Burrows et al. 1991; Werner 1991), and the Miombo woodland of southern Africa (Isango 2007). No more than approximately $10 \%$ of savannas arise in India and South-East Asia (Werner 1991; Bond and Wilgen 1996; Furley 2004). Only a small number of studies of Indonesian savannas have been done (Whitten et al. 1996; Monk et al. 2000).

Savannas in Indonesia are located from west to the east across the archipelago, such as Cidaon (Ujung Kulon National Park), Badeto (Pangandaran), Merbabu (Mt. Merbabu), Cikasur (Mt. Argopuro), Oro-oro Ombo (Mt. Semeru), Bromo (Mt. Bromo), Bekol (Baluran), Sadengan (Alas Purwo), Sembalun (Rinjani), Tambora (Sumbawa), Komodo Island (Flores), and East Sumba savanna (Sumba Island). These savannas occur across a steep gradient of rainfall (Whitten et al. 1996; Monk et al. 2000). The savannas in West Java receive mean annual rainfall of $2,940 \mathrm{~mm}$, with $68.9 \%$ of this rainfall occurring during the wet season, which lasts from October to April (Rosleine and Suzuki 2013). On the east side of Java Island, rainfall is lower. The savannas here have mean annual rainfall of $1,500 \mathrm{~mm}$, with the wet season being more pronounced ( $80 \%$ of total rain), usually from November to April and dry season occurring from May up to October (Hakim et al. 2005). In Bali and Lombok Islands, the savannas receive mean annual rainfall of 1,200-1,500 $\mathrm{mm}$ and in East Nusa Tenggara, the average annual rainfall drops to $800-900 \mathrm{~mm}$ (Monk et al. 2000; Gunawan 2010)

Flores is an exotic island that has volcanic landscape geomorphology and is located at a dry zone in a morphoclimatic classification (Verstappen 2014). The savannas are found at different elevations on this island, but studies of the species composition of savannas along the elevation gradient, especially in Flores, have not been done. Therefore, the objective of this research was to analyze the dissimilarity in species composition of savannas along the elevation gradient in Flores using the ordination method. 


\section{MATERIALS AND METHODS}

\section{Study area}

Nusa Tenggara, Indonesia is a group of small-andmedium-sized islands stretching from Lombok Island in the west to Tanimbar Island in the east. East Nusa Tenggara consists of several islands, with the main ones being Flores, Komodo and Sumba which are geographically located at $119^{\circ} 21^{\prime} 30.04^{\prime \prime} \mathrm{E}-121^{\circ} 47^{\prime} 22.91^{\prime \prime} \mathrm{E}$ and $8^{\circ} 57^{\prime} 31.95^{\prime \prime} \mathrm{S}$ $8^{\circ} 12^{\prime} 57.41^{\prime \prime} \mathrm{S}$. The sampling of savannas in East Nusa Tenggara was concentrated on Flores Island which covered Komodo Island Natural Reserve, Nagekeo District, East Manggarai, and Ende (Figure 1).

\section{Procedures}

Sixteen sampling plots, each measuring 20 × 20 m were made to sample the vegetation (tree layer and the groundcover layer) and were spread over several locations from lowland (0 to $100 \mathrm{~m}$ asl), midland (101 to $500 \mathrm{~m}$ asl), to upland (500 $\mathrm{m}$ asl up). The lowland plots were located in Komodo and Padar Islands (West Manggarai District), Riung and Mbay (Nagekeo District) and Nangaraya (East Manggarai District); the midland plots at Mbay (Nagekeo District) and Nangabara (East Manggarai District), and the upland plots at Ratabeke, Kelimutu (Ende District) (Figure 1).

The geographical position and elevation of each plot were marked with handheld GPS GARMIN GPS 76CSX. In each plot, we identified the species and estimated the percentage of cover. Identification and plant material collection record was conducted in the Herbarium Baliensis within the Bali Botanical Garden-LIPI, as this botanical garden has many record collections from eastern parts of Indonesia, which is its specialty.

\section{Data analyses}

Using species cover data we analyzed the plant species composition among the savannas. The data were transformed using square-root prior to the construction of a resemblance matrix based on Bray-Curtis similarity (Valessini 2009). A Non-metric Multidimensional Scaling (NMDS) ordination diagram was then generated based on the resemblance matrix. The results of NMDS ordination were tested for significance using one-way ANOSIM (analysis of similarity). SIMPER (Similarity Percentage) analysis was then used to explore the relative contribution of individual species to the dissimilarity among savannas. This multivariate analysis was conducted using the PRIMER V.6 package (Clarke and Gorley 2005).

\section{RESULTS AND DISCUSSION}

As many as 40 species of plants were found in all of the sampling plots, consisting of 39 genus and 22 families. Leguminosae, Asteraceae and Poaceae were the three most dominant families (Figure 2). There were slight differences in species composition among the savannas, as described in the results from NMDS ordination analysis in Figure $2\left(\mathrm{R}_{\text {ANOSIM }}=0.4\right)$. The NMDS results are reliable as the $2 \mathrm{~d}$ stress level is small (0.06). The plots were basically clustered into three clusters (Figure 3 ). The plots located inside a cluster have $20 \%$ similarity in terms of their species composition. There were few plots that belong to lowland savannas which were inside the midland cluster and similarly, there were plots belonging to midland cluster that was located inside the upland cluster. These plots are the transition plots, from lowland to midland and from midland to upland sites.

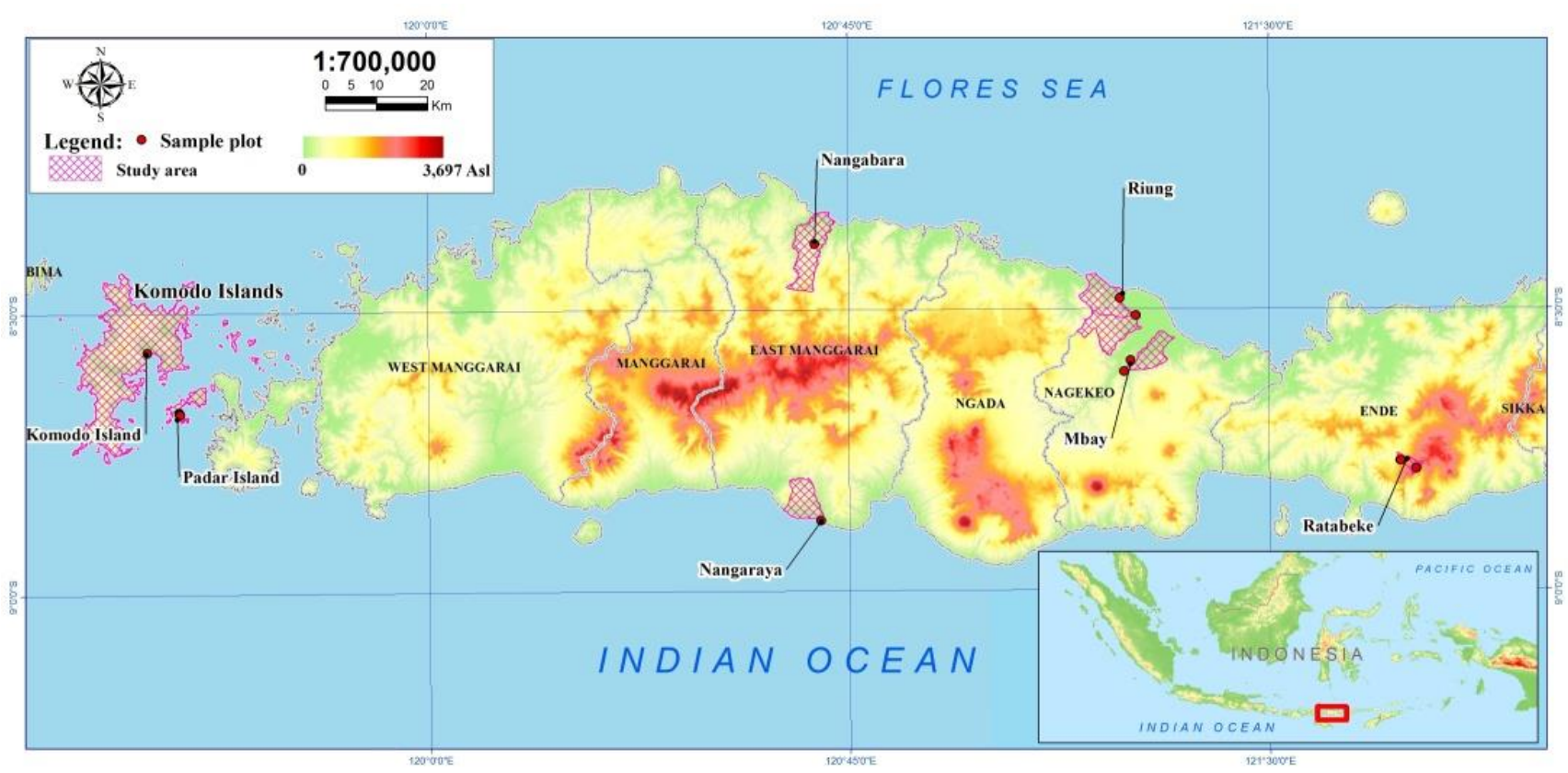

Figure 1. Study area of savannas and the sampling plots 
Table 1. Results from SIMPER analysis for lowland group (Elev 0-100), showing species that contribute the most in terms of similarity of plots within the group.

\begin{tabular}{lccc}
\hline Species & Av.Abund & Av.Sim & Contrib (\%) \\
\hline Themedea arguens & 10.21 & 23.10 & 73.07 \\
Zoesya sp. & 2.05 & 2.95 & 9.33 \\
Crotalaria sp. & 2.32 & 2.80 & 8.87 \\
\hline
\end{tabular}

Table 2. Results from SIMPER analysis for midland group (Group Elev 101-500), showing species that contribute the most in terms of similarity of plots within the group.

\begin{tabular}{lccc}
\hline Species & Av.Abund & Av.Sim & Contrib (\%) \\
\hline Zoesya sp. & 6.14 & 14.57 & 63.46 \\
Adenanthera pavonina & 1.75 & 6.76 & 29.44 \\
\hline
\end{tabular}

Table 3. Results from SIMPER analysis for upland group (Group Elev500-up), showing species that contribute the most in terms of similarity of plots within the group.

\begin{tabular}{lccc}
\hline Species & Av.Abund & Av.Sim & Contrib (\%) \\
\hline Cyperus sp. & 9.28 & 17.23 & 23.72 \\
Polygala paniculata & 7.17 & 16.09 & 22.16 \\
Imperata cylindrica & 6.08 & 15.29 & 21.05 \\
Melastoma malabathricum & 5.34 & 13.06 & 17.98 \\
Chromolaena odorata & 5.50 & 10.95 & 15.08 \\
\hline
\end{tabular}

Tables 1, 2, and 3 show the species which contribute the most in terms of similarity of plots within each group. For lowland group (elevation 0 to $100 \mathrm{~m}$ asl), Themeda arguens, a grass species, had the highest average abundance and therefore highest percentage contribution, followed by another grass species, Zoesya sp. and a shrub Crotalaria sp. In the midland group (Table 2) Zoesya sp. had the highest abundance then followed by Adenanthera pavonina. In the upland group (Table 3), grass species Cyperus sp. had the highest abundance and percentage contribution, followed by Polygala paniculata, Imperata cylindrica (grass), Melastoma malabathricum (shrub) and also the invasive exotic species of shrub Chromolaena odorata.

Table 3 shows that I. cylindrica or cogon grass was one of the species which contribute to the upland savanna site such as on Mt. Kelimutu Flores. Similar results were reported by (Sutomo et al. 2011; Sutomo 2013) that $I$. cylindrica occurred at high elevation savanna such as on Mt. Rinjani Volcano in Lombok, and on Mt. Merapi (Java) impacted by the volcanic eruption. In west Java $I$. cylindrica also occurred on Mt. Galunggung eruption site as described by Pratiwi (1989), and, in Thailand Highlands (Andrews 1983). Therefore, it is possible that this species is a characteristic of savanna species at high elevation and disturbed sites.
Tables 4, 5 and 6 describe plant community composition in each of the savanna locations and their average abundance difference with the paired sites. Lowland savanna plant community consisted of species such as $T$. arguens, Zoesya sp., C. odorata, Crotalaria sp., A. pavonina, Ocimum sp., L. camara in the groundcover layer, whereas at the tree layer there were Ziziphus jujube, and Borassus flabellifer. Midland savanna had almost similar composition with lowland savanna, except for the occurrence of I. cylindrica in the groundcover layer and Leucaena leucocephala in the tree layer. Upland savanna plant species composition was Cyperus sp., P. paniculata, I. cylindrica, M. malabathricum, C. odorata, Centella asiatica, Vaccinium sp., and Cymbopogon sp. Themeda and Zoesya grasses occurred at lowland and midland savannas but with different abundance (lowland had higher abundance) whereas I. cylindrica grass or cogon grass was found at midland and also upland savannas where at upland the cogon grass was more abundant than at midland.

Table 4. Pairwise comparison between lowland group (Elev 0-100) $\&$ midland group (Elev 101-500). Average dissimilarity $=87.03$.

\begin{tabular}{lccc}
\multicolumn{1}{c}{ Species } & $\begin{array}{c}\text { Midland } \\
\text { group } \\
\text { Av.Abund }\end{array}$ & $\begin{array}{c}\text { Upland } \\
\text { group } \\
\text { Av.Abund }\end{array}$ & $\begin{array}{c}\text { Contrib } \\
(\%)\end{array}$ \\
\hline Themedea arguens & 10.21 & 0.47 & 25.41 \\
Zoesya sp. & 2.05 & 6.14 & 14.64 \\
Chromolaena odorata & 1.64 & 1.67 & 6.64 \\
Crotalaria sp. & 2.32 & 0.00 & 6.18 \\
Leucas lavandulaefolia & 0.00 & 1.82 & 5.21 \\
Imperata cylindrica & 0.00 & 1.67 & 4.60 \\
Adenanthera pavonina & 0.12 & 1.75 & 4.56 \\
Occimum sp. & 0.70 & 1.05 & 4.30 \\
Lantana camara & 0.54 & 0.58 & 2.77 \\
Zizyphus jujuba & 0.94 & 0.33 & 2.60 \\
Borassus flabellifer & 0.08 & 0.58 & 1.77 \\
Leucaena leucocephala & 0.00 & 0.58 & 1.46 \\
\hline
\end{tabular}

Table 5. Pairwise comparison between lowland group (Elev 0-100) $\&$ upland group (Elev 500-up). Average dissimilarity $=96.07$.

\begin{tabular}{lccc}
\hline \multicolumn{1}{c}{ Species } & $\begin{array}{c}\text { Midland } \\
\text { group } \\
\text { Av.Abund }\end{array}$ & $\begin{array}{c}\text { Upland } \\
\text { group } \\
\text { Av.Abund }\end{array}$ & $\begin{array}{c}\text { Contrib } \\
(\%)\end{array}$ \\
\hline Themedea arguens & 10.21 & 0.00 & 16.30 \\
Cyperus sp. & 0.00 & 9.28 & 15.42 \\
Polygala paniculata & 0.00 & 7.17 & 12.04 \\
Imperata cylindrica & 0.00 & 6.08 & 10.28 \\
Melastoma malabathricum & 0.00 & 5.34 & 9.04 \\
Chromolaena odorata & 1.64 & 5.50 & 7.98 \\
Centella asiatica & 0.00 & 3.12 & 4.93 \\
Crotalaria sp. & 2.32 & 0.00 & 3.85 \\
Zoesya sp. & 2.05 & 0.00 & 3.79 \\
Vaccinium sp. & 0.00 & 1.80 & 3.25 \\
Cymbopogon sp. & 0.37 & 1.50 & 2.87 \\
Zizyphus jujuba & 0.94 & 0.00 & 1.59 \\
\hline
\end{tabular}




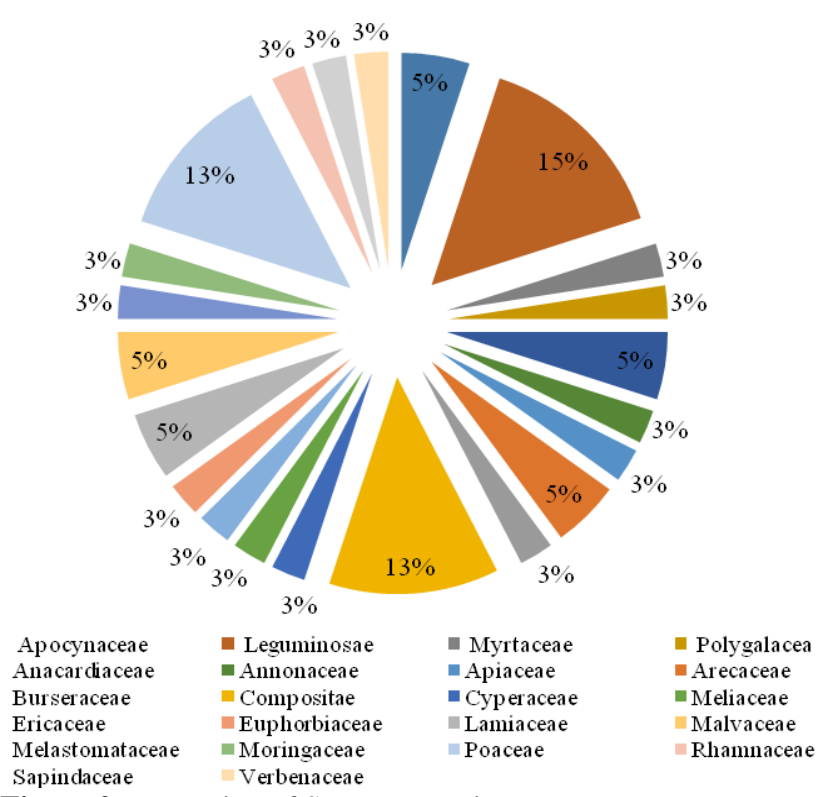

Figure 2. Proportion of Savanna species

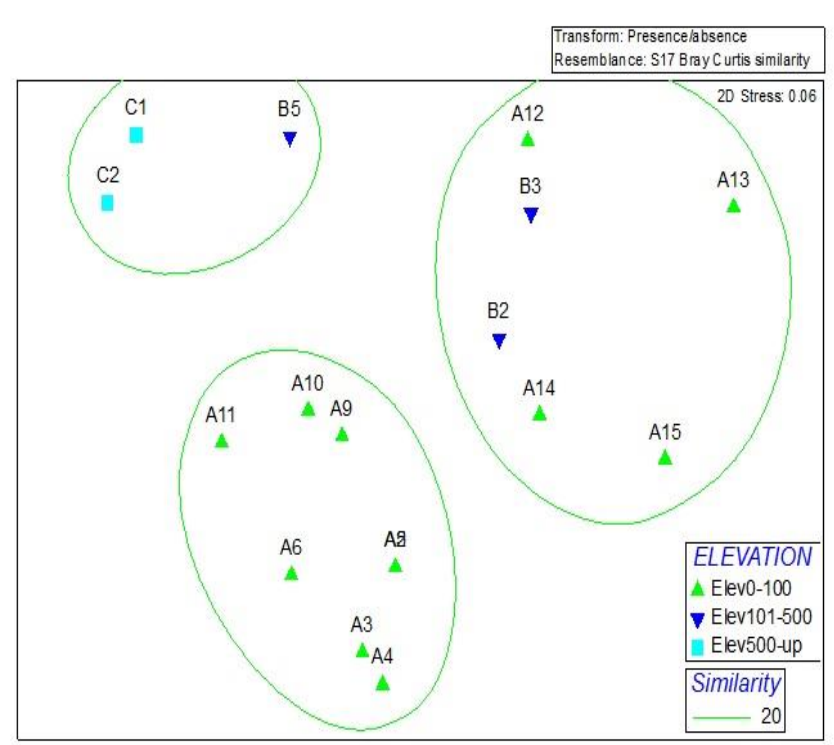

Figure 3. Results of NMDS ordination analysis of savanna vegetation composition in Flores. Stress level 0.06. $\mathrm{R}_{\mathrm{ANOSIM}}=0.4$ Number of permutations $=999$.

Table 6. Pairwise comparison between midland group (Elev 101500) \& upland group (Elev 500-up). Average dissimilarity = 89.14

\begin{tabular}{lccc}
\multicolumn{1}{c}{ Species } & $\begin{array}{c}\text { Midland } \\
\text { group } \\
\text { Av. abund }\end{array}$ & $\begin{array}{c}\text { Upland } \\
\text { group } \\
\text { Av. abund }\end{array}$ & $\begin{array}{c}\text { Contrib } \\
(\%)\end{array}$ \\
\hline Cyperus sp. & 0.00 & 9.28 & 17.15 \\
Polygala paniculata & 0.00 & 7.17 & 13.39 \\
Zoesya sp. & 6.14 & 0.00 & 11.50 \\
Melastoma malabathricum & 0.00 & 5.34 & 10.06 \\
Imperata cylindrica & 1.67 & 6.08 & 8.29 \\
Chromolaena odorata & 1.67 & 5.50 & 7.47 \\
Centella asiatica & 0.00 & 3.12 & 5.48 \\
Vaccinium sp. & 0.00 & 1.80 & 3.62 \\
Leucas lavandulaefolia & 1.82 & 0.00 & 3.53 \\
Adenanthera pavonina & 1.75 & 0.00 & 3.32 \\
Cymbopogon sp. & 0.00 & 1.50 & 3.01 \\
\hline
\end{tabular}

In terms of invasive alien species, the lowland and midland savannas were invaded by $L$. camara whereas the $C$. odorata occurred both at midland and upland savannas. Invasive exotic species pose serious threat to the existence of savannas, and invasions are occurring in different regions at different pace. For example, flammable nonnative grasses are invading the Llanos savannas in Brazil, and there are also very aggressive African grasses that invade and increase fire intensity (Baruch 1996). These African grasses are (i) Melinis minutiflora, very successful in savannas above 600 meters above sea level, and rather abundant in Colombia, (ii) Hyparrhenia rufa, in lowland savannas with poor soils and marked dry season, (iii) Panicum maximum, in humid and relatively fertile areas, and (iv) Brachiaria mutica in periodically flooded savannas (Baruch 1996). All these species generally occur on the wetter (and/or) more fertile habitats of the savanna (Baruch 1996; Beatty et al. 2015). In Asia, several exotic species have also been reported as invasive such as $C$. odorata (Bangladesh, Nepal), L. camara (Bangladesh, Maldives, Nepal, Pakistan, Philippine), Mimosa invisa, Mimosa pigra (Laos, Malaysia), Mikania micrantha (Malaysia, Nepal, Philippine), L. leucocephala (Maldives, Philippine), Acacia mangium (Philippine) and Eucalyptus camaldulensis (Pakistan, Philippine) (Pallewatta et al. 2003; Setyawati et al. 2015). Most of the species are also found to be invasive in Indonesia. Species such as $L$. camara, and $C$. odorata, as well as $M$. micrantha, are significant threats to the savanna ecosystem in Indonesia, beside woody alien species Acacia nilotica (Sutomo 2017). This study concluded that species composition of savannas along the elevation gradient in Flores Island was only slightly different.

\section{ACKNOWLEDGEMENTS}

We thank Research Center for Biology, Indonesian Institute of Sciences (LIPI), Komodo National Park and Kelimutu National Park. Also, we thank our technician who already retired last year, I Ketut Sandi and I Nyoman Peneng for their assistance in the field and helping with plant identification process.

\section{REFERENCES}

Andrews AC. 1983. Imperata cylindrica in the highlands of Northern Thailand: Its productivity and status as a weed. Mountain Res Dev 3 (4): 386-388.

Baruch Z. 1996. Ecophysiological aspects of the invasion of African grasses and their impact on biodiversity and function of Neotropical savannas. In: Solbrig O, Medina E, Silva JF (eds.). Biodiversity and Savanna Ecosystem Processes: A Global Perspective. Springer Verlag, Berlin.

Beatty R, Russel-Smith J, Van der Werf GR. 2015. International Savanna Fire Management Initiative. Institute for the advanced studies of sustainability, Darwin:

Bond WJ, Wilgen BWv. 1996. Fire and Plants. 1st ed. Chapman \& Hall, London.

Burrows WH, Carter JO, Scanlan JC, Anderson ER. 1991. Management of Savannas for Livestock Production in North-East Australia: Contrast across the Tree-Grass Continuum. In: Werner PA (eds) Savanna Ecology and Management. Blackwell Scientific Publication, London. 
Clarke KR, Gorley RN. 2005. PRIMER: Plymouth Routines In Multivariate Ecological Research (Version 6.0). Plymouth: PRIMERE Ltd.

Frost PGH, Menaut JC, Walker BH, Medina E, Solbrig O. T. 1986 Responses of savannas to stress and disturbance. In: Scholes RJ, Walker BH (eds.). An African Savanna: Synthesis of the Nylsvley Study. Cambridge University Press, Cambridge.

Furley P. 2004. Tropical savannas. Progr Phys Geogr 28 (4): 581-598.

Gunawan. 2010. Rancangan Teknis Rehabilitasi Kawasan Konservasi Taman Nasional Manupeu Tanah Daru. Manupeu Tanah Daru National Park, Ministry of Forestry, Sumba. [Indonesian]

Hakim L, Leksono AS, Purwaningtyas D, Nakagoshi N. 2005. Invasive plant species and the competitiveness of wildlife tourism destination: a case of Sadengan feeding area at Alas Purwo National Park. J Int Dev Cooper 12 (1): 35-45.

Isango JA. 2007. Stand Structure and Tree Species Composition of Tanzania Miombo Woodlands: A Case Study from Miombo Woodlands of Community Based Forest Management in Iringa District. Paper presented at the Management of Indigenous Tree Species for Ecosystem Restoration and Wood Production in SemiArid Miombo Woodlands in Eastern Africa, Tanzania.

Monk KA, De Fretes Y, Reksodihardjo-Lilley, Gayatri. 2000. Ekologi Nusa Tenggara dan Maluku (Vol. V). Prenhallindo, Jakarta. [Indonesian]

Pallewatta N, Reaser JK, Gutierrez AT. 2003. Invasive Alien Species in South-Southeast Asia: National Reports \& Directory of Resources. Global Invasive Species Programme, Cape Town, South Africa.

Pratiwi. 1989. Vegetation Analysis of the Lava Area from Eruption Product of Galunggung Mountain West Java Indonesia. Buletin Penelitian Hutan 512: 23-32. [Indonesian]
Rosleine D, Suzuki E. 2013. Secondary succession at abandoned grazing sites. Pangandaran Nature Reserve, West Java, Indonesia. Tropics 21 (3): 91-103.

Setyawati, Titiek, Narulita, Sari, Bahri IP, Raharjo GT. 2015. A Guide Book of Invasive Plant Species in Indonesia. Research, Development and Innovation Agency. Ministry of Environment and Forestry, Bogor. [Indonesian]

Sutomo. 2013. Ecological Succession on Volcanic Ecosystem of Mount Merapi Indonesia and Its Implication For Restoration. SEAMEOBIOTROP, Bogor. [Indonesian]

Sutomo. 2017. Ecology of Savanna Ecosystems in Indonesia. [Dissertation], Edith Cowan University, Australia

Sutomo, Hobbs RJ, Cramer VA. 2011. Plant community establishment on the volcanic deposit following nuees ardentes of Mount Merapi: diversity and floristic variation. Biodiversitas 12 (4): 86-91. [Indonesian]

Valessini F. 2009. NBIO528 multivariate techniques and community ecology: Course handout. Centre for Fish and Fisheries Research Murdoch University, Perth.

Verstappen, Herman Th. 2014. Garis Besar Geomorfologi Indonesia. Gadjah Mada University Press, Yogyakarta. [Indonesian]

Werner PA. 1991. Savanna Ecology and Management: Australian Perspective and Intercontinental Comparisons. Blackwell Scientific Publication, London.

Whitten T, Soeriaatmadja RE, Afiff SA. 1996. The ecology of Indonesia series volume II: The ecology of Java and Bali (Vol. 2). Periplus, Hongkong. 